\title{
PENGARUH MORALITAS INDIVIDU DAN PENGENDALIAN INTERNAL TERHADAP KECENDERUNGAN KECURANGAN AKUNTANSI (STUDI EKSPERIMEN PADA MAHASISWA JURUSAN AKUNTANSI FAKULTAS EKONOMI UNIVERSITAS MULAWARMAN SAMARINDA)
}

\author{
Oleh : \\ Ibnu Abni Lahaya* \\ ( ${ }^{\star D}$ osen Fakultas Ekonomi Universitas Mulawarman Samarinda)
}

\begin{abstract}
Penelitian ini bertujuan untuk membuktikan perbedaan kecenderungan individu dalam melakukan kecurangan akuntansi antara individu yang memiliki level moral yang tinggi dan individu yang memiliki level moral yang rendah dalam kondisi terdapat elemen pengendalian internal maupun tidak terdapat elemen pengendalian internal dengan setting eksperimen laboratorium menggunakan surrogate mahasiswa S1 Akuntansi Fak. Ekonomi Universitas Mulawarman. Hasil penelitian ini menunjukkan bahwa individu dengan level moral rendah kecenderungan melakukan kecurangan akuntansi lebih tinggi dibandingkan individu yang memiliki level moral yang tinggi. Peranan pengendalian internal sebagai salah satu faktor yang dapat memengaruhi dalam menekan atau mencegah kemungkinan terjadinya kecurangan akuntansi tersebut. Hal ini dikarenakan peraturan juga dapat menjadi alat pencegah yang efektif agar seseorang tidak melakukan hal-hal yang tidak sesuai dengan peraturan yang ada.
\end{abstract}

Kata kunci: kecurangan akuntansi, pengendalian internal, moralitas individu

\section{PENDAHULUAN}

Menurut Wells (2007), kecurangan akuntansi (fraud) mengacu kepada kesalahan akuntansi yang dilakukan secara sengaja dengan tujuan menyesatkan pembaca/pengguna laporan keuangan. Tujuan ini dilakukan dengan motivasi negatif guna mengambil keuntungan individu atau pihak-pihak tertentu. Menurut Association Of Certified Fraud Examiners (ACFE), kecurangan akuntansi dapat digolongkan menjadi tiga jenis: kecurangan dalam laporan keuangan, penyalahgunaan aktiva dan korupsi. Di Indonesia, kasus kecurangan akuntansi yang terjadi baik pada sektor publik maupun sektor swasta mempunyai bentuk yang hampir sama, hanya berbeda dalam hal tempat atau objek. Pada sektor publik, bentuk dari KKA adalah kebocoran anggaran (Aranta, 2014).

Kecurangan akuntansi sangat erat hubungannya dengan etika. Kecurangan akuntansi merupakan suatu tindakan ilegal. Menurut Baucus (1994) dalam Hernandez dan Groot (2007), secara umum perilaku ilegal adalah bagian dari perilaku tidak etis, oleh karena itu ada hukum yang harus ditegakkan sebagai bagian dari usaha penegakkan standar moral. Penelitian dari Hernandez dan Groot (2007) menemukan bahwa etika dan lingkungan pengendalian 
akuntansi merupakan dua hal yang sangat penting terkait kecenderungan seseorang dalam melakukan kecurangan akuntansi.

Beberapa penelitian di bidang etika menggunakan teori perkembangan moral untuk mengobservasi dasar individu melakukan suatu tindakan. Salah satu yang sering digunakan adalah teori mengenai level penalaran moral Kohlberg. Mengetahui level penalaran moral seseorang akan menjadi dasar untuk mengetahui kecenderungan individu melakukan suatu tindakan tertentu, terutama yang berkaitan dengan dilema etika, berdasarkan level penalaran moralnya. Welton (1994) menyatakan bahwa kemampuan individu dalam menyelesaikan dilema etika dipengaruhi oleh level penalaran moralnya. Hasil penelitian Wilopo (2006) menemukan bahwa semakin tinggi level penalaran moral individu akan semakin cenderung tidak berbuat kecurangan akuntansi. Bernardi (1994) dan Ponemon (1993) dalam Moroney (2008) menemukan bahwa semakin tinggi level moral individu akan semakin sensitif terhadap isu-isu etika.

Selain faktor rasionalisasi yang berkaitan erat dengan etika, faktor lain yang menjadi penyebab kecurangan akuntansi adalah faktor kesempatan. Salah satu penyebab adanya kesempatan untuk melakukan kecurangan akuntansi adalah kurangnya pengawasan dan lemahnya pengendalian internal organisasi. Coram et al. (2008) menjelaskan bahwa organisasi yang memiliki fungsi internal audit akan lebih dapat mendeteksi kecurangan akuntansi. Penelitian Hogan et al. (2008) menemukan bahwa auditor berperan dalam mengurangi faktor kesempatan (opportunity) dalam kecurangan akuntansi.

Penelitian ini akan mengolaborasikan teori mengenai kecurangan akuntansi dan etika dalam konteks pemerintahan daerah di Indonesia. Level moral individu (tinggi dan rendah) dan elemen pengendalian internal organisasi (ada dan tidak ada) merupakan faktor yang akan diteliti sebagai penyebab terjadinya kecurangan akuntansi dalam penelitian ini.

Berdasarkan latar belakang masalah dan hasil penelitian sebelumnya, penelitian ini dilakukan untuk mengetahui variasi yang terjadi pada kecenderungan kecurangan akuntansi yang akan dijelaskan oleh dua variabel, yaitu variabel moralitas individu dan variabel pengendalian internal untuk menjawab permasalahan:

a. Apakah terdapat perbedaan kecenderungan kecurangan akuntansi antara individu yang memiliki level moralitas tinggi dan level moralitas rendah?

b. Apakah terdapat perbedaan kecenderungan kecurangan akuntansi antara individu dalam kondisi terdapat elemen pengendalian internal dan tidak terdapat elemen pengendalian internal?

c. Apakah terdapat interaksi yang signifikan antara moralitas individu dan pengendalian internal dalam memengaruhi kecurangan akuntansi?

\section{LANDASAN TEORI}

\section{Teori Agensi}

Jensen dan Meckling (1976) mendefinisikan hubungan keagenan sebagai kontrak antara satu orang atau lebih yang bertindak sebagai prinsipal (yaitu pemegang saham) yang menunjuk orang lain sebagai agen (yaitu manajer) untuk melakukan jasa untuk kepentingan prinsipal termasuk mendelegasikan kekuasaan dalam pembuatan keputusan. Manajer sebagai pengelola perusahaan lebih banyak mengetahui informasi internal dan prospek perusahaan di masa yang akan datang dibandingkan pemilik (pemegang saham). Situasi ini 
akan memicu munculnya suatu kondisi yang disebut sebagai asimetri informasi (information asymmetry). Asimetri informasi merupakan suatu kondisi ketidakseimbangan dalam memperoleh informasi antara pihak manajemen sebagai penyedia informasi (prepaper) dengan pihak pemegang saham sebagai pengguna informasi (user).

\section{Kecurangan akuntansi}

Ikatan Akuntan Indonesia (IAI) menjelaskan kecurangan akuntansi sebagai: (1) Salah saji yang timbul dari kecurangan dalam pelaporan keuangan yaitu salah saji atau penghilangan secara sengaja jumlah atau pengungkapan dalam laporan keuangan untuk mengelabui pemakai laporan keuangan, (2) Salah saji yang timbul dari perlakuan tidak semestinya terhadap aktiva (seringkali disebut dengan penyalahgunaan atau penggelapan) yang berkaitan dengan pencurian aktiva entitas yang berakibat laporan keuangan tidak disajikan sesuai dengan Prinsip Akuntansi yang Berlaku Umum (PABU) di Indonesia. Perlakuan tidak semestinya terhadap aktiva entitas dapat dilakukan dengan berbagai cara, termasuk penggelapan tanda terima barang atau uang, pencurian aktiva, atau tindakan yang menyebabkan entitas membayar barang atau jasa yang tidak diterima oleh entitas. Perlakuan tidak semestinya terhadap aktiva dapat disertai dengan catatan atau dokumen palsu atau yang menyesatkan dan dapat menyangkut satu atau lebih individu di antara pegawai atau pihak ketiga.

Perspektif kecurangan menurut Bologna (1993) dari sudut pandang akuntansi dan audit, kecurangan adalah penggambaran yang salah dari fakta material dalam buku besar atau laporan keuangan. Pernyataan yang salah dapat ditujukan pada pihak luar organisasi seperti pemegang saham atau kreditor, atau pada organisasi itu sendiri dengan cara menutupi atau menyamarkan penggelapan uang, ketidakcakapan, penerapan dana yang salah atau pencurian atau penggunaan aktiva organisasi yang tidak tepat oleh petugas, pegawai dan agen. Kecurangan dapat juga ditujukan pada organisasi oleh pihak luar, misalnya, penjual, pemasok,kontraktor, konsultan dan pelanggan, dengan cara penagihan yang berlebihan, dua kali penagihan, substitusi material yang lebih rendah mutunya, pernyataan yang salah mengenai mutu dan nilai barang yang dibeli, atau besarnya kredit pelanggan.

Cressey (1953) mengemukakan tiga pemicu fraudatauyang dikenal dengan Fraud Triangle sebagaimana yang ditunjukkan dalam gambar 2.1 berikut.

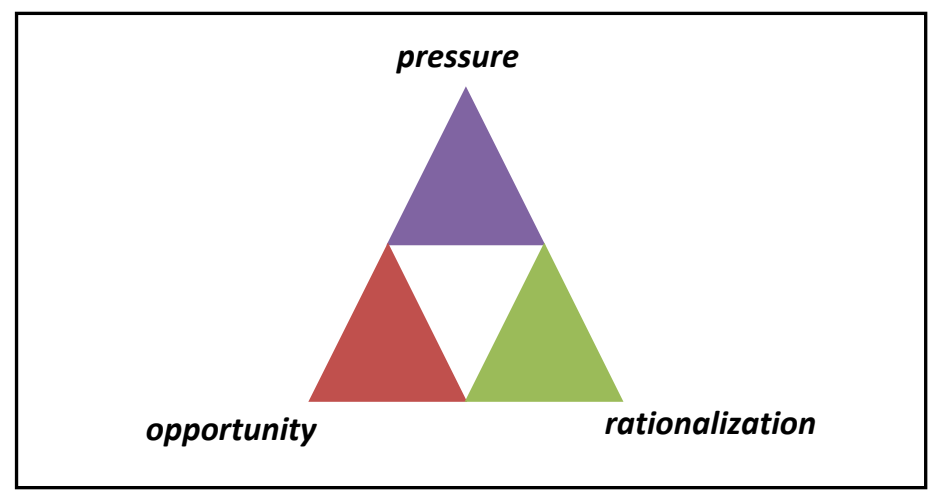


a) Tekanan (unshareable pressure/ incentive). Tekanan melakukan fraud, antara lain faktor ekonomi, alasan emosional (iri/ cemburu, balas dendam, kekuasaan, gengsi), nilai (values) dan karena dorongan keserakahan.

b) Adanya kesempatan/ peluang (perceived opportunity).Kesempatan yaitu kondisi atau situasi yang memungkinkan seseorang melakukan atau menutupi tindakan tidak jujur. Biasanya hal ini dapat terjadi karena adanya internal control perusahaan yang lemah, kurangnya pengawasan, dan/atau penyalahgunaan wewenang.

c) Rasionalisasi (rationalization). Rasionalisasi ditunjukkan saat pelaku mencari pembenaran sebelum melakukan kejahatan, bukan sesudah melakukan tindakan tersebut. Rasionalisasi diperlukan agar si pelaku dapat mencerna perilakunya yang ilegal untuk tetap mempertahankan jati dirinya sebagai orang yang dipercaya, tetapi setelah kejahatan dilakukan, rasionalisasi ini ditinggalkan karena sudah tidak dibutuhkan lagi.

\section{Penalaran moral}

Salah satu teori perkembangan moral yang banyak digunakan dalam penelitian etika adalah model Kohlberg. Kohlberg (1969) menyatakan bahwa moral berkembang melalui tiga tahapan, yaitu tahapan pre-conventional, tahapan conventional dan tahapan post-conventional. Welton et al. (1994) menyatakan bahwa kemampuan individu dalam menyelesaikan dilema etika dipengaruhi oleh level penalaran moralnya. Hasil dari beberapa studi yang dipaparkan dalam Liyanarachi (2009) menunjukkan bahwa level penalaran moral individu mereka akan mempengaruhi perilaku etis mereka. Orang dengan level penalaran moral yang rendah berperilaku berbeda dengan orang yang memiliki level penalaran moral yang tinggi ketika menghadapi dilema etika. Semakin tinggi level penalaran moral seseorang, maka individu tersebut semakin mungkin untuk melakukan 'hal yang benar'.

\section{Pengendalian internal}

Definisi sistem pengendalian internal menurut Peraturan Pemerintah No.60 tahun 2008 tentang Sistem Pengendalian Internal Pemerintah (SPIP) adalah proses yang integral pada tindakan dan kegiatan yang dilakukan secara terus menerus oleh pimpinan dan seluruh pegawai untuk memberikan keyakinan memadai atas tercapainya tujuan organisasi melalui kegiatan yang efektif dan efisien, keandalan pelaporan keuangan, pengamanan aset negara, dan ketaatan terhadap peraturan perundang-undangan. Boynton et al.(2003) mendefinisikan aktivitas pengendalian sebagai kebijakan dan prosedur yang membantu memastikan bahwa perintah manajemen telah dilakukan. Aktivitas pengendalian membantu memastikan bahwa tindakan yang diperlukan berkenaan dengan risiko yang diambil untuk pencapaian tujuan organisasi.

Coram et al. (2008) menjelaskan bahwa organisasi yang memiliki fungsi audit internal akan lebih dapat mendeteksi kecurangan akuntansi. Pengendalian akuntansi merupakan bagian dari sistem pengendalian internal, meliputi struktur organisasi, metode, dan ukuran-ukuran yang dikoordinasikan terutama untuk menjaga kekayaan organisasi serta mengecek ketelitian dan keandalan data akuntansi (Bastian, 2006). 


\section{KERANGKA KONSEP DAN PENGEMBANGAN HIPOTESIS}

Beberapa penelitian di bidang etika menggunakan teori perkembangan moral untuk mengobservasi dasar individu melakukan tindakan. Salah satu yang sering digunakan adalah teori mengenai level penalaran moral Kohlberg. Mengetahui level penalaran moral seseorang akan menjadi dasar untuk mengetahui kecenderungan individu melakukan tindakan tertentu, terutama yang berkaitan dengan dilema etika, berdasarkan level penalaran moralnya.

Penelitian dari Hernandez dan Groot (2007) menemukan bahwa etika dan lingkungan pengendalian merupakan dua hal yang sangat penting terkait kecenderungan seseorang dalam melakukan kecurangan akuntansi. Penelitian ini akan mengolaborasikan teori mengenai kecurangan akuntansi dan etika dalam sebuah studi eksperimen dengan konteks pemerintahan daerah. Level moral individu (tinggi dan rendah) dan elemen pengendalian internal organisasi (ada dan tidak ada) merupakan faktor yang akan diteliti sebagai penyebab terjadinya kecuranganakuntansi.

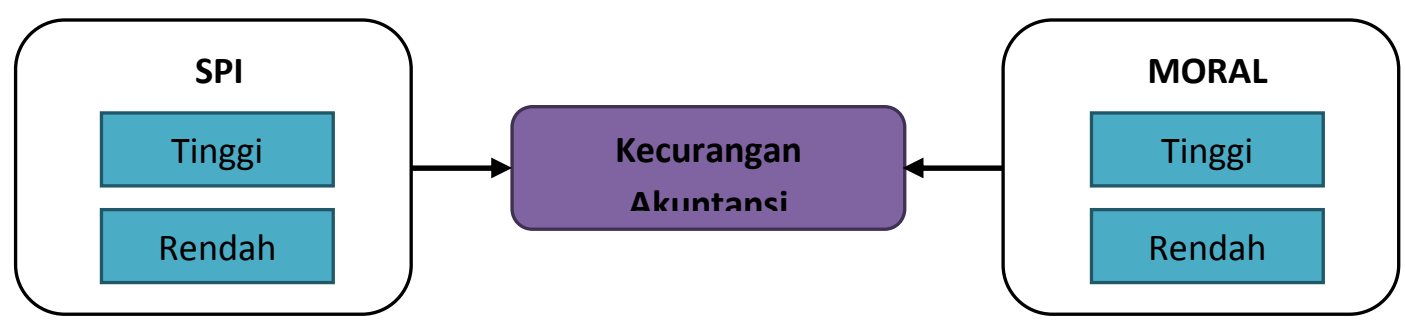

Pengendalian internal merupakan salah satu faktor yang akan diteliti sebagai penyebab kecurangan akuntansi dalam penelitian ini. Coram et al. (2008) menemukan bahwa organisasi yang memiliki fungsi audit internal akan lebih dapat mendeteksi kecurangan akuntansi dan melaporkannya sendiri. Hogan et al. (2008) menemukan bahwa auditor internal berperan penting dalam mengurangi faktor kesempatan dalam kecurangan akuntansi.

Faktor lain penyebab terjadinya kecurangan akuntansi yang akan diteliti dalam penelitian ini adalah faktor etika yang berkaitan erat dengan moralitas individu. Welton (1994) menyatakan bahwa kemampuan individu dalam menyelesaikan dilema etika dipengaruhi oleh level penalaran moralnya. Hasil dari beberapa studi yang dipaparkan dalam Liyanarachchi (2009) menunjukkan bahwa level penalaran moral individu akan mempengaruhi perilaku etis mereka. Orang dengan level penalaran moral yang rendah berperilaku berbeda dengan orang yang memiliki level penalaran moral yang tinggi ketika menghadapi dilema etika. Dalam tindakannya, orang yang memiliki level penalaran moral rendah cenderung akan melakukan hal-hal yang menguntungkan dirinya sendiri dan menghindari hal-hal yang dapat menimbulkan sanksi hukum.

Kondisi elemen pengendalian internal di dalam organisasi (ada dan tidak ada pengendalian internal) dapat mempengaruhi individu dengan level moral rendah untuk cenderung melakukan atau tidak melakukan kecurangan akuntansi. Namun bagi individu dengan level moral tinggi, kondisi ada dan tidak ada elemen pengendalian internal organisasi tidak akan membuatnya melakukan kecurangan akuntansi yang akan merugikan organisasi dan masyarakat. Berdasarkan hal tersebut, maka hipotesis yang diajukan dalam penelitian ini adalah: 
$\mathrm{H}_{1}$ : Terdapat perbedaan kecenderungan kecurangan akuntansi antara individu yang memiliki level moralitas tinggi dan level moralitas rendah

$\mathrm{H}_{2}$ : Terdapat perbedaan kecenderungan kecurangan akuntansi antara individu dalam kondisi terdapat elemen pengendalian internal dan tidak terdapat elemen pengendalian internal

$\mathrm{H}_{3}$ : Terdapat interaksi yang signifikan antara moralitas individu dengan pengendalian internal

\section{METODE PENELITIAN}

\section{Jenis Penelitian}

Jenis penelitian ini adalah kuantitatif dengan metode eksperimen. Setting eksperimen ini adalah eksperimen laboratorium atau eksperimen pada lingkungan buatan (Sekaran dan Bougie, 2010) untuk mengontrol situasi penguasa dan perlakuan pada subjek (Bordens dan Abbot, 2008) dirancang untuk memenuhi tujuan penelitian ini yaitu mengetahui hubungan kausal atas moralitas individu dan pengendalian internal terhadap kecurangan akuntansi.

\section{Desain dan Prosedur Penelitian}

Penelitian ini menggunakan rancangan eksperimen faktorial $2 \times 2$ untuk mengamati kecenderungan individu melakukan kecurangan akuntansi dengan membagi partisipan ke dalam empat grup, yaitu:

(1) Grup 1, kelompok level moral tinggi dalam kondisi ada elemen pengendalian internal;

(2) Grup 2, kelompok level moral tinggi dalam kondisi tidak terdapat elemen pengendalian internal;

(3) Grup 3, kelompok level moral rendah dalam kondisi terdapat elemen pengendalian internal; dan

(4) Grup 4: kelompok level moral rendah dalam kondisi tidak terdapat elemen pengendalian internal.

\section{Sumber Data dan Partisipan Penelitian}

Data yang digunakan dalam penelitian ini adalah data primer yang diperoleh berdasarkan hasil jawaban partisipan dalam kuesioner yang dibagikan.Partisipan dalam eksperimen ini adalah subjek pengganti atau surogasi. Subjek pengganti dalam eksperimen ini menggunakan 120 mahasiswa S1 Fakultas Ekonomi Jurusan Akuntansi yang telah menempuh mata kuliah Akuntansi Keuangan, Akuntansi Manajemen dan Akuntansi Sektor Publik.

\section{Definisi dan Pengukuran Variabel}

\section{a. Kecurangan akuntansi}

Kecurangan akuntansi adalah perlakuan tidak semestinya dengan sengaja atas salah saji yang timbul dalam pelaporan keuangan sebagai bentuk kecurangan yang berakibat laporan keuangan tidak disajikan sesuai dengan 
prinsip akuntansi yang berlaku umum. Kecurangan akuntansi diukur dengan meminta partisipan untuk memberikan pendapatnya dalam pertanyaan kasus mengenai pengadaan barang/jasa di instansi pemerintah. Partisipan menjawab pertanyaan tersebut setelah membaca skenario eksperimen. Skala Likert $1-10$ digunakan untuk mengukur respons dari partisipan. Semakin tinggi partisipan memberikan angka penilaiannya, semakin cenderung partisipan tersebut berbuat curang. Skenario yang digunakan merupakan pengembangan dari skenario yang digunakan oleh Puspasari (2012) dan Dewi (2014).

\section{b. Moralitas individu}

Moralitas individu merupakan sifat moral yang berkaitan dengan keputusan baik dan buruk atas asas dan nilai kehidupan. Indikator moralitas individu berdasarkan teori perkembangan moral Kohlberg (1969) yang diadopsi oleh Dewi (2014) bahwa moral berkembang melalui tiga tahapan yaitu tahapan pre-conventional, tahapan conventional dan tahapan post-conventional. Pengukuran moralitas individu menggunakan instrumen Defining Issues Test (Dewi, 2014) melalui 6 (enam) butir instrumen yang mengukur setiap tahapan moralitas melalui kasus dilema etika akuntansi.

\section{c. Pengendalian internal}

Pengendalian internal merupakan proses yang dilakukan secara integral oleh pimpinan dan seluruh pegawai terhadap tindakan dan kegiatan yang dilakukan secara terus menerus untuk memberikan keyakinan memadai atas tercapainya tujuan organisasi melalui kegiatan yang efektif dan efisien, keandalan pelaporan keuangan, pengamanan aset negara, dan ketaatan terhadap peraturan perundang-undangan. Variabel pengendalian internal dalam penelitian ini merupakan variabel aktif yang diberikan perlakuan atau manipulasi untuk keperluan penelitian eksperimen.Pengukuran variabel pengendalian internal menggunakan skenario yang dikembangkan dari penelitian Puspasari (2012) yang terdiri dari dua skema dalam skenario yaitu ada elemen pengendalian internal dan tidak ada elemen pengendalian internal.

\section{Pilot Test}

Pilot test (penelitian pendahuluan) dilakukan untuk mengetahui apakah kasus yang diberikan dapat dipahami oleh partisipan atau tidak (Cooper dan Schindler, 2003). Pilot test juga dilakukan untuk meningkatkan validitas internal. Beberapa perubahan terhadap desain awal kuesioner kemungkinan dilakukan dengan masukan yang sesuai dengan tujuan penelitian. Pilot test dilakukan terhadap 20 orang mahasiswa S1 Akuntansi Universitas Mulawaraman. Sarandari partisipan akan menjadi masukan bagi peneliti untuk melakukan perbaikan terhadap materi eksperimen.

\section{Teknik Analisis Data}

Berbagai pengujian data yang dilakukan dalam penelitian ini yaitu meliputi distribusi frekuensi untuk statistik deskriptif, uji homogenitas, dan uji normalitas data. Setelah itu dilakukan analisis varians (ANOVA) untuk menguji hubungan antara satu variabel dependen (skala metrik) dengan satu atau lebih variabel independen (skala nonmetrik atau kategorikal dengan kategori lebih dari dua).

\section{Statistik deskriptif}


Analisis statistik deskriptif ditujukan untuk memberikan gambaran umum mengenai partisipan yang dijelaskan dalam tabel distribusi frekuensi. Tabel tersebut berguna untuk menunjukan demografi partisipan, sedangkan deskripsi mengenai variabel-variabel penelitian menggunakan tabel distribusi frekuensi yang menunjukkan kisaran teoritis, kisaran sesungguhnya, mean, dan standar deviasi yang diperoleh dari hasil jawaban partisipan yang diterima.

\section{Uji homogenitas}

Homogeneity of variance yaitu variabel dependen harus memiliki varian yang sama dalam setiap kategori variabel independen (Ghozali, 2012). Jika terdapat lebih dari satu variable independen, maka harus ada homogeneity of variance di dalam cell yang dibentuk oleh variabel independen kategorikal. SPSS memberikan uji ini dengan nama Levene's Test of Homogeneity of Variance. Jika nilai Levene Test signifikan (probabilitas $<0,05$ ) maka grup memiliki varian yang berbeda dan hal ini menyalahi asumsi. Jadi yang dikehendaki adalah Levene Test tidak signifikan (probabilitas $=0,05$ ).

\section{Uji normalitas}

Uji normalitas bertujuan mengetahui apakah dalam sebuah model regresi, baik variabel dependen, variabel independen, atau keduanya, mempunyai distribusi normal (Ghozali, 2012: 160). Uji normalitas dapat dilihat dari uji statistik non parametric Kolmogorov-Smimov. Jika signifikansi nilai Kolmogorov-Smimov di atas alfa yang ditetapkan (tidak signifikan), dikatakan bahwa data residual terdistribusi secara normal (Ghozali, 2012: 163).

\section{Uji hipotesis}

Untuk menguji hipotesis dalam penelitian ini digunakan uji statistik Two Way Analysis of Variance(Two-Way Anova)dengan program SPSS versi 20, dengan alasan penelitian ini menggunakan dua variabel independen berskala data kategorik yaitu variabel pengendalian internal (ada dan tidak) dan variabel moralitas (tinggi dan rendah) serta satu variabel terikat berskala data kuantitatif/numerik (interval atau rasio) yaitu variabel kecurangan akuntansi.

\section{HASIL PENELITIAN DAN PEMBAHASAN}

\section{Cek Manipulasi}

Cek manipulasi dilakukan dengan menguji partisipan untuk menentukan benar atau salah dengan dua pertanyaan. Pertanyaan pertama adalah mengenai tugas partisipan selaku Kepala Dinas X. Pertanyaan kedua adalah mengenai gambaran elemen pengendalian internal di Dinas $X$. Hasil analisis cek manipulasi menunjukkan bahwa dari 120 partisipan, hanya sebanyak 116 partisipan (96,7\%) yang lolos cek manipulasi dan lolos dari eliminasi penalaran moral, sehingga partisipan yang tidak lolos cek manipulasi dan tidak lolos eliminasi penalaran moral adalah sebanyak 4 orang $(3,3 \%)$.

\section{Uji validitas dan reliabilitas}

Hasil uji validitas menunjukkan bahwa nilai koefisien validitas atau nilai spearman correlation $(r)$ untuk semua instrumen lebih dari 0,3 . Hal ini berarti, 
semua instrumen penelitian dapat dinyatakan valid. Dengan kata lain, instrumen penelitian tersebut memiliki ketepatan dan kecermatan dalam melakukan fungsi ukurnya. Sedangkan, hasil uji reliabilitas diketahui bahwa nilai Cronbach Alpha untuk instrumen pengukuran moralitas individu, nilainya lebih dari 0,6. Hal itu berarti, instrumen penelitian dapat dikatakan reliabel. Dengan kata lain, hasil pengukuran dalam penelitian ini dapat dipercaya.

\section{Uji normalitas}

Hasil pengujian normalitas dengan Kolmogorov-Smirnov Test menunjukkan nilai Asymp. Sig 0,102 (di atas 0,05), dengan hasil tersebut dapat dikatakan bahwa data terdistribusi dengan normal sehingga memenuhi salah satu asumsi ANOVA.

\section{Uji homogenitas}

Levene's Testdilakukan untuk mengetahui apakah keempat perlakuan (perlakuan 1,2,3, dan 4) mempunyai varian yang sama. Hasil uji statistik menunjukkan nilai levene statistic sebesar 0,167 (diatas 0,05). Hal ini menunjukkan bahwa setiap kelompok subjek memenuhi varian yang sama sehingga telah memenuhi asumsi ANOVA.

\section{Pengujian Hipotesis}

Hasil analisisTest of Between-Subjects Effects untuk membandingkan antar kelompok/perlakuan menunjukkan bahwa nilai koefisien Sig untuk hipotesis 1, 2, dan 3 (hipotesis efek moralitas individu, efek pengendalian internal, dan interaksi) seluruhnya lebih kecil dari alpha yang ditetapkan (5\%). Dengan demikian dapat disimpulkan sebagai berikut:

a. Ho yang menyatakan tidak terdapat perbedaan kecenderungan kecurangan akuntansi antara individu yang memiliki level moralitas tinggi dan level moralitas rendah ditolak sehingga dapat dinyatakan bahwa terdapat perbedaan kecenderungan kecurangan akuntansi antara individu yang memiliki level moralitas tinggi dan level moralitas rendah.

b. Ho yang menyatakan tidak terdapat perbedaan kecenderungan kecurangan akuntansi antara individu dalam kondisi terdapat elemen pengendalian internal dan tidak terdapat elemen pengendalian internal ditolak sehingga dapat dinyatakan bahwa terdapat perbedaan kecenderungan kecurangan akuntansi antara individu dalam kondisi terdapat elemen pengendalian internal dan tidak terdapat elemen pengendalian internal

c. Ho yang menyatakan tidak terdapat interaksi yang signifikan antara moralitas individu dengan pengendalian internal ditolak sehingga dapat dinyatakan bahwa terdapat interaksi yang signifikan antara moralitas individu dengan pengendalian internal.

\section{Pembahasan}

Hasil penelitian menunjukkan bahwa grup 4 dan grup 3 dengan perlakuan level moral rendah memiliki mean yang lebih tinggi dibandingkan grup 1 dan grup 2 dengan perlakuan level moral tinggi. Hasil analisis menunjukkan bahwa nilai koefisien Sig untuk hipotesis1 (hipotesis efek moralitas individu) yaitu 0,000 lebih 
kecil dari alpha yang ditetapkan (5\%). Ho ditolak sehingga dapat dinyatakan bahwa terdapat perbedaan kecenderungan kecurangan akuntansi antara individu yang memiliki level moralitas tinggi dan level moralitas rendah. Dapat juga disimpulkan bahwa hipotesis pertama didukung karena terdapat perbedaan kecenderungan melakukan kecurangan akuntansi yang diakibatkan oleh perlakuan moralitas individu tanpa memperhatikan perlakuan lainnya.

Hipotesis 2 (hipotesis efek pengendalian internal) juga diterima dengan nilai koefisien Sig yaitu $0,012(<0,05)$ sehingga dapat dinyatakan bahwa terdapat perbedaan kecenderungan kecurangan akuntansi antara individu dalam kondisi terdapat elemen pengendalian internal dan tidak terdapat elemen pengendalian internal. Dapat juga disimpulkan bahwa hipotesis kedua didukung karena terdapat perbedaan kecenderungan melakukan kecurangan akuntansi yang diakibatkan oleh perlakuan pengendalian internal (ada dan tidak) tanpa memperhatikan perlakuan lainnya. Bukti mengenai kekuatan pengaruh variabel interaksi ditunjukkan dengan nilai koefisien Sig yaitu $0,000 \quad(<0,05)$ yang menunjukkan bahwa ada saling ketergantungan antara level moral individu dengan kondisi elemen pengendalian internal, dengan demikian hipotesis ketiga didukung. Kondisi ada atau tidak ada pengendalian internal dalam sebuah organisasi akan membuat individu dengan level moral tertentu untuk cenderung melakukan kecurangan akuntansi. Perubahan level kondisi elemen pengendalian internal (ada dan tidak ada elemen pengendalian internal akan mengakibatkan dampak perubahan pada individu dengan level moral tertentu (tinggi atau rendah) untuk melakukan kecurangan akuntansi.

Perbandingan mean grup 4 dan grup 2 menunjukkan bahwa terdapat perbedaan yang signifikan antara grup 4 dan grup 2. Individu yang memiliki level penalaran moral rendah (Grup 4) lebih cenderung melakukan kecurangan akuntansi dibandingkan individu yang memiliki level penalaran moral tinggi (Grup 2) dalam kondisi tidak terdapat elemen pengendalian internal. Dalam keadaan tidak terdapat elemen pengendalian internal dalam organisasi, individu dengan level penalaran moral rendah akan memanfaatkan kondisi tersebut untuk kepentingan pribadinya (self-interest), misalnya melakukan kecurangan akuntansi. Hal ini sesuai dengan yang ada dalam stage 2 Kohlberg (level preconventional) yaitu individu yang memiliki level penalaran moral rendah memiliki motivasi utama untuk kepentingan pribadinya. Perbandingan mean grup 4 dan grup 3 juga menunjukkan bahwa terdapat perbedaan yang signifikan antara grup 4 dan grup 3. Hal ini berarti individu dengan level penalaran moral rendah dalam kondisi tidak terdapat elemen pengendalian internal (Grup 4) cenderung melakukan kecurangan akuntansi jika dibandingkan dengan individu dengan level penalaran moral rendah dalam kondisi terdapat elemen pengendalian internal (Grup 3).

Hasil penelitian ini menunjukkan bahwa individu dengan level moral rendah kecenderungan melakukan kecurangan akuntansi lebih tinggi dibandingkan individu yang memiliki level moral yang tinggi. Semakin tinggi moralindividu, semakin individu tersebut memperhatikan kepentingan yang lebih luas dan universal daripada kepentingan organisasinya semata, apalagi kepentingan individunya. Semakin tinggi level moral individu, semakin ia berusaha untuk menghindarkan diri dari kecenderungan melakukan kecurangan akuntansi yang akan merugikan banyak pihak. Atau dengan kata lain, individu yang memiliki level penalaran moral tinggi akan lebih sensitif terhadap isu-isu etika, sehingga akan cenderung melakukan perbuatan yang etis. Selain itu, 
pengendalian internal melalui peraturan dan sanksi hukum dapat menekan atau mencegah kemungkinan terjadinya kecurangan akuntansi. Hal ini dikarenakan peraturan juga dapat menjadi alat pencegah yang efektif agar seseorang tidak melakukan hal-hal yang tidak sesuai dengan peraturan yang ada. Menurut Puspasari (2012), peraturan yang ada dalam organisasi merupakan suatu bentuk pengendalian internal yang berfungsi sebagai alat untuk memastikan tujuan organisasi tercapai. Wilopo (2006) juga mengungkapkan semakin efektif pengendalian internal di perusahaan, semakin rendah kecenderungan kecurangan akuntansi oleh manajemen perusahaan.

\section{KESIMPULAN DAN SARAN}

\section{Kesimpulan}

Berdasarkan rumusan masalah, tujuan penelitian, landasan teori, hipotesis dan hasil penelitian, maka simpulan dari penelitian ini adalah terdapat perbedaan kecenderungan individu dalam melakukan kecurangan akuntansi antara individu yang memiliki level moral yang tinggi dan individu yang memiliki level moral yang rendah. Selain itu juga terdapat perbedaan kecenderungan individu dalam melakukan kecurangan akuntansi antara individu dalam kondisi terdapat elemen pengendalian internal maupun tidak terdapat elemen pengendalian internal. Hasil dari penelitian ini juga mengindikasikan terdapat interaksi antara level moral individu dengan pengendalian internal. Artinya perubahan pada satu level faktor level moral atau pada kondisi pengendalian internal, akan menyebabkan perubahan individu dalam melakukan kecurangan akuntansi. Hal ini dapat terlihat dari hipotesis ketiga. Individu yang memiliki level penalaran moral tinggi cenderung tidak melakukan kecurangan akuntansi dibandingkan dengan individu yang memiliki level penalaran rendah.

Elemen pengendalian internal dapat menjadi alat yang mampu mengurangi kecenderungan melakukan kecurangan akuntansi bagi individu dengan level penalaran moral rendah. Dalam kondisi terdapat elemen pengendalian internal, individu yang memiliki level penalaran moral rendah cenderung tidak melakukan kecurangan akuntansi. Sebaliknya dalam kondisi tidak terdapat elemen pengendalian internal, individu dengan level penalaran moral rendah akan cenderung melakukan kecurangan akuntansi.

\section{Keterbatasan dan saran}

Berdasarkan hasil penelitian dan beberapa kendala yang dihadapi dalam penelitian ini, maka masih diperlukan pengembangan dan perbaikan guna memperoleh hasil penelitian yang lebih baik pada penelitian-penelitian selanjutnya. Penelitian selanjutnya diharapkan dapat memasukkan variabelvariabel yang terkait demografis partisipan (gender, posisi di organisasi, pengalaman bekerja, usia, dan pendidikan) untuk melihat pengaruh variabelvariabel tersebut terhadap kecenderungan kecurangan akuntansi. Penelitian selanjutnya juga disarankan untuk lebih fokus pada desain eksperimen yang lebih sempurna agar lebih dapat menggambarkan kondisi yang lebih nyata. 


\section{DAFTAR PUSTAKA}

Albrecht, S. W. dan C. Albrecht. 2004. Fraud Examination and Prevention. Australia: Thomson, South-Western.

Arnold, D. dan L. Ponemon. 1991. Internal Auditors' Perceptions of WhistleBlowing and The Influence of Moral Reasoning: An Experiment. Auditing: A Journal of Practice \& Theory Vol. 10.

Bastian, I. 2006. Akuntansi Sektor Publik: Suatu Pengantar. Erlangga.

Bernardi, R. dan S. Guptill. 2008. Social Desirability Response Bias, Gender and Factors Influencing Organizational Commitment: An International Study. Journal of Business Ethics Vol. 25.

Betts, D. 2009. The Psychology of Fraud: What Makes Employee Cross The Line?. Joint ACFE/ISACA.

Bologna, J. 1993. Handbook of Corporate Fraud. Boston; ButterworthHeinemann.

Booz-Allen, and Hamilton. 1999. Earned Value Management Tutorial Module 6: Metrics, Performance Measurements and Forecasting. boozallen.com/about/article_newsideas

Boynton, W. C. dan R.N. Johnson. Modern Auditing. Eight Edition. John Wiley and Son. Inc

Brickley, J. A. and C. M. James. 1987. The Takeover Market, Corporate Board Composition and Ownership Structure: The Case Banking. The Journal of Law and Economics, Vol. 30

Cooper, D.R. and P. Schindler. 2003. Business Research Methods. Edisi ke-8. McGraw Hill, New York.

Coram, P. Ferguson, C. dan Moroney, R. 2008. Internal Audit, Alternative Internal Audit Structures and The Level of Misapropriation of Assets Fraud. Accounting and Finance vol. 48

Cressey, D. 1953. Other People's Money: a Study in the Social Psychology of Embezzlement. Glencoe. IL: Free Press.

Desmita. 2005. Psikologi Perkembangan. Bandung: PT. Remaja Rosdakarya

Dewi, Gusti Ayu Ketut Rencana Sari. 2014. Pengaruh Moralitas Individu Dan Pengendalian Internal Pada Kecurangan Akuntansi (Studi Eksperimen pada Pemerintah Daerah Provinsi Bali). Tesis. Program Pascasarjana Universitas Udayana

Eisenhardt, K. M. 1989. Building Theories from Case Study Research. Academy of Management Review. Vol. 14

Falikhatun, 2007. Interaksi Informasi Asimetri, Budaya Organisasi dan Group Cohensiveness Dalam Hubungan Antara Partisipasi Penganggaran dan 
Budgetary Slack (Studi Kasus Pada Rumah Sakit Umum Daerah Se-Jawa Tengah). Publikasi Simposium Nasional Akuntansi (SNA) X, Makasar; 2628 Juli 2007.

Ghozali, 2012. Aplikasi Analisis Multivariate Dengan Program IBM SPSS 19. Edisi Keenam, Penerbit Universitas Diponegoro.

Hair, J.F. JR., Anderson, Tatham, and Black. 2006. Multivariate Data Analysis. Six Edition. New Jersey : Pearson.

Hernandez, J. R. dan T. Groot. 2007. Corporate Fraud: Preventive Controls Which Lower Corporate Fraud. Amsterdam Research Centre in Accounting.

Hogan, C. E., Z. Rezaee., R. A. Riley., dan U. K. Velury. 2008. Financial Statement Fraud: Insights From The Academic Literature. Auditing: A Journal of Practice and Theory Vol. 27.

Jensen, M. and W.H. Meckling. 1976. Theory of the Firm: Managerial Behavior, Agency Cost, and ownership Structure. Journal of Financial Economics Vol. 3.

Kerlinger, F. N. 2000. Azas-azas Penelitian Behavioral. Yogyakarta: Gadjah Mada University Press

Kohlberg, L. 1969. Stage and Sequence: The Cognitive-Development Approach Moral Action to Socialization. In D. A. Goslin (Ed). Handbook of Socialization Theory and Research. Chicago: RandMcNally.

Liyanarachi, G dan C. Newdick. 2009. The Impact of Moral Reasoning and Retaliation on Whistle-Blowing: New-Zealand Evidence. Journal of Business Ethics Vol. 89.

Maroney, J. J. dan R. E. McDevitt. 2008. The Effects of Moral Reasoning on Financial Reporting Decisions in a Post Sarbanes-Oxley Environment. Behavioral Research of Accounting Vol. 15

Mulyadi. 2009. Auditing. Penerbit Salemba Empat, Jakarta.

Puspasari, N. 2012. Pengaruh Moralitas Individu dan Pengendalian Internal terhadap Kecenderungan Kecurangan Akuntansi: Studi Eksperimen pada Konteks Pemerintahan Daerah. Tesis. Yogyakarta: Program Pasca Sarjana. Universitas Gajah Mada.

Ramamoorti, S. 2008. The Psychology and Sociology of Fraud: Integrating the Behavioral Sciences Component Into Fraud and Forensic Acounting Curricula. Issues in Accounting Education Vol. 23.

Rest, J. R. 2000. A Neo-Kohlbergian Approach To Morality Research. Journal of Moral Education vol 29

Scott, W. R. 2000. Financial Accounting Theory. Second Edition. Canada: Prentice Hall. 
Sekaran, Uma dan Bougie. 2010. Research Methods For Business, Jakarta: Salemba Empat.

Shivdasani, A. 1993. Board Composition, Ownership Structure, and Hostile Takeovers. Journal of Accounting and Economics Vol.16.

Wells, J. T. 2007. Corporate Fraud Handbook: Prevention and Detection. Second Edition. John Wiley and Sons Inc.

Welton, R. E., J. R Davis dan M. LaGroune. 1994. Promoting The Moral Development Of Accounting Graduate Students. Accounting Education: International Journal Vol. 3.

Wilopo. 2006. Analisis Faktor-Faktor yang Berpengaruh Terhadap Kecenderungan Kecurangan Akuntansi : Studi pada Perusahaan Publik dan Badan Usaha Milik Negara (BUMN) di Indonesia. Jurnal Riset Akuntansi Indonesia Vol.9. 


\title{
PENGARUH PERCEIVED RISK TERHADAP PEMBELIAN ONLINE MELALUI JEJARING SOSIAL FACEBOOK
}

\author{
Oleh : \\ Maulita* \\ Musdalifah* \\ ( ${ }^{\star}$ Dosen Politeknik Negeri Samarinda)
}

\begin{abstract}
ABSTRAK
Facebook merupakan salah satu media yang tidak hanya menyediakan fasilitas pertemanan tetapi juga memberikan fasilitas untuk melakukan pembelian secara online. Melalukan transaksi online melalui facebook memberikan beberapa kemudahan tetapi tetap saja mengandung unsur ketidakpastian sehingga menimbulkan resiko bagi konsumennya. Resiko dalam penelitian ini dilihat dari 8 dimensi yaitu Financial Risk, Psycological risk, Time risk, Privacy risk, Fraud risk, Product risk, Information risk, dan Delivery risk. Masing-masing dimensi ini diukur dengan menggunakan skala likert 1 sampai 6.

Populasi dan sampel dalam penelitian ini adalah mahasiswa Politeknik Negeri Samarinda yang pernah menggunakan facebook untuk melakukan transaksi pembelian online dan pengumpulan data dilakukan dengan metode survey. Sampel dalam penelitian ini sebanyak 150 orang. Analisis data yang digunakan dalam penelitian ini yaitu menggunakan regresi.

Hasil penelitian ini menunjukkan bahwa dari 8 dimensi resiko yang timbul dalam pembelian online, hanya fraud risk, information risk, dan delivery risk yang berpengaruh terhadap keputusan untuk melakukan pembelian produk online, sedangkan dimensi lainnya tidak berpengaruh.
\end{abstract}

Kata kunci : perceived risk, keputusan pembelian, facebook

\section{PENDAHULUAN}

Facebook tidak hanya media pertemanan namun dapat dimanfaatkan sebagai media perdagangan online. Perdagangan online melalui media facebook memiliki kemudahan, keuntungan, namun resiko tetap mengintai. Hal ini mengingat bahwa transaksi perdagangan online di media jejaring facebook berada di dunia maya, maka terdapat ketidakpastian yang sangat tinggi. Barang yang diperjualbelikan juga bersifat maya karena marang tersebut tersaji dalam bentuk informasi-informasi, baik berupa tulisan, foto ataupun vidio (Jarvenpaa dan Tractinsky, 1999). Konsumen tidak bisa benar-benar melihat, menyentuh, mendengar ataupun merasakan pengalaman terhadap barang yang akan dibelinya secara nyata.

Unsur ketidakpastian tersebut kemudian menimbulkan perceived risk dalam benak konsumen (Naiyi, 2004). Masih banyak konsumen yang menilai bahwa melakukan pembelian secara online memiliki resiko yang cukup signifikan. Baik berupa performance risk, financial risk, psychological risk, dan time risk harus diperhatikan dalam pembelian online (Stone dan Gronhaug, 1993). Perkembangan facebook sebagai media perdagangan online yang 
semakin meningkat walaupun tetap mengandung resiko yang kemudian membuat peneliti tertarik melakukan penelitian mengenai pengaruh resiko yang dirasakan (perceived risk) terhadap pembelian online di media jejaring sosial facebook.

\section{KAJIAN PUSTAKA}

\section{Sejarah Jejaring Sosial}

Sejak komputer dapat dihubungkan satu dengan lainnya dengan adanya internet banyak upaya awal untuk mendukung jejaring sosial melalui komunikasi antar komputer.NSitus jejaring sosial diawali oleh Classmates.com pada tahun 1995 yang berfokus pada hubungan antar mantan teman sekolah dan SixDegrees.com pada tahun 1997 yang membuat ikatan tidak langsung. Dua model berbeda dari jejaring sosial yang lahir sekitar pada tahun 1999 adalah berbasiskan kepercayaan yang dikembangkan oleh Epinions.com, dan jejaring sosial yang berbasiskan pertemanan seperti yang dikembangkan oleh Uskup Jonathan yang kemudian dipakai pada beberapa situs UK regional di antara 1999 dan 2001. Inovasi meliputi tidak hanya memperlihatkan siapa berteman dengan siapa, tetapi memberikan pengguna kontrol yang lebih akan isi dan hubungan. Pada tahun 2005, suatu layanan jejaring sosial MySpace, dilaporkan lebih banyak diakses dibandingkan Google dengan Facebook, pesaing yang tumbuh dengan cepat.

Jejaring sosial mulai menjadi bagian dari strategi internet bisnis sekitar tahun 2005 ketika Yahoo meluncurkan Yahoo! 360 ${ }^{\circ}$. Pada bulan juli 2005 News Corporation membeli MySpace, diikuti oleh ITV (UK) membeli Friends Reunited pada Desember 2005. Diperkirakan ada lebih dari 200 situs jejaring sosial menggunakan model jejaring sosial ini.dan saat ini jejaring yang saat ini sedang booming adalah Face book.

\section{Facebook}

Facebook adalah sebagai penyedia jejaring social yang menjadikan kita untuk saling berhubungan dengan teman, sesame pekerja, dan dengan orang lain yang senang dengan berbagi atau dari lapisan semua pengguna. Jadi jelaslah bahwa Facebook itu bukanlah "Halaman Buku" melainkan suatu situs komunitas dimana kita dapat saling berkomunikasi dengan pengguna lain di dunia maya. Facebook saat ini memang menjadi trend dalam situs social networking. Lebih lanjut dikatakan ada beberapa hal yang membuat Facebook menjadi trend di saat ini adalah antara lain :

1. Privacy : anggota bisa mengatur berbagai informasi yang boleh ditampilkan dan tidak boleh ditampilkan sampai mengatur siapa saja yang boleh melihatnya.

2. Feed : memberikan informasi yang terjadi pada jejaring facebook anda.

3. Mobile : dengan perangkat bergerak/ponsel kita bisa mengakses account Facebook.

4. Photo Album : jumlah foto yang bisa diupload tidak terbatas.

5. Status : dengan adanya pembuatan status yang bisa diberikan komentar, semakin membuat aktivitas jejaring akan semakin aktif.

6. Application : menyediakan aplikasi-aplikasi yang menyenangkan dan tidak membosankan. 
7. Advense (iklan) : dengan menggunakan Faceebook makan dapat membuat iklan dengan mudah dan bisa dengan mudah dan menghasilkan pendapatan dengan metode CPC (Cost per Clik).

\section{Electronic Commerce}

Electronic commerce didefnisikan beragam oleh para peneliti. Pada penelitian ini, penulis mengambil defenisi electronic commerce yang dikemukakan oleh Urbaczewski et al. (2002) yakni penggunaan jaringan computer untuk melakukan penjualan dan pembelian barang, jasa atau informasi secara elektronik dengan para supplier, konsumen atau competitor atau antar konsumen. Defenisi ini memerlukan dua persyaratan agar suatu perniagaan dapat disebut sebagai electronic commerce. Syarat pertama adalah perniagaan dilakukan secara online dan kedua yaitu adanya pertukaran nilai (exchange value).

Perniagaan secara online mengindikasikan adanya penggunaan jaringan computer yang menjadi dasar teknologi informasinya untuk mendukung akumulasi data, manipulasi atau komunikasi. Dimana jaringan yang digunakan bisa berupa jaringan terbuka seperti internet ataupun tertutup seperti intanet yang hanya digunakan kalangan tertentu yang dizinkan pengelola jaringan. Focus penelitian ini adalah jaringan terbuka yaitu internet melalui media jejaring social face book. Pertukaran nilai (exchange value) yang diakukan melalui electronic commerce melibatkan hal yang berkaitan dengan barang, jasa, informasi, uang dan waktu kenyamanan.

Tiga elemen berbeda yang ditemui di e-commerce. Pertama, vendor yakni organisasi atau orang yang menjual barang atau jasa secara elektronik. Maka disebut sebagai electronic vendor atau e-vendor. Kedua, konsumen yang menggunakan jasa elektronik untuk mencari informasi, memesan jasa atau membeli produk. Ketiga, teknologi berupa perangkat keras (computer, internet, telpon seluler), perangkat lunak yang dapat digunakan untuk bertransaksi (cowles et al. 2002).e-commerce berdasarkan pasarnya da dua kategori : business to business (B2B) dan e-commerce dan Business to consumer (B2C) ecommerce. Dan facebook adalah kategori B2C(Business to consumer).

\section{Perilaku Konsumen}

Perilaku konsumen berkaitan dengan perceived risk terutam dalam perilaku konsumen online dan proses pengambilan keputusan pembelian. Dengan memahami perilaku konsumen kita dapat mengetahui bagaimana proses pengambilan keputusan pembelian. Keputusan pembelian ini kemudian menentukan kepuasan konsumen dan resiko yang akan dirasakan konsumen apabila keputusan yang diambil tidak tepat.

Schiffman dan Kanuk (2008:6) mengatakan bahwa perilaku konsumen adalah perilaku yang ditampilkan oleh konsumen dalam mencari, membeli, menggunakan, mengevaluasi dan membuang produk, jasa dan ide-ide. Sedangkan menurut Loudon dan Bitta (2001:3) perilaku konsumen merupakan proses pengambilan keputusan dan kegiatan fisik individu yang terlibat dalam mengevaluasi, memperoleh, menggunakan, atau membuang barang dan jasa. Maka dapat dikatakan bahwa perilaku konsumen merupakan suatu proses yang menyangkut keputusan konsumen dalam melakukan pembelian, serta tindakan dalam memperoleh, memakai, mengkonsumsi, dan menghabiskan produk. 
Setiap hari kita membuat berbagai macam keputusan yang menyangkut segala kehidupan kita. Namun dalam membuat keputusan, kita tidak berpikir tentang bagaimana kita membuat keputusan tersebut dan apa saja yang terlibat dalam proses pengambilan keputusan itu sendiri. Menurut Kotler (2006:137) terdapat beberapa faktor yang mempengaruhi keputusan pembelian konsumen, yaitu fator budaya, sosial, pribadi, dan psikologi dari pembeli tersebut.

\section{Keputusan Pembelian Konsumen}

Secara umum, keputusan adalah pemilihan dari dua atau lebih alternatif pilihan (Schiffman dan Kanuk, 2008:437). Dengan kata lain untuk membuat keputusan harus terdapat alternative pilihan. Sebaliknya jika konsumen tidak memiliki alternatif untuk memilih maka tidak dapat dikategorikan sebagai pengambilan keputusan.. Menurut Schiffman dan kanuk (2008:438) pembuatan keputusan konsumen dapat dilihat sebagai 3 tahapan keputusan yang berbeda tetapi saling berhubungan, antara lain :

1. The input stage, tahapan ini mempengaruhi konsumen tentang kebutuhannya akan produk atau jasa yang terdiri dari 2 sumber informasi penting yaitu kegiatan pemasaran perusahaan dan lingkungan sosial budayanya. Pengaruh kumulatif dari dua hal tersebut yang menjadi masukan dalam mempengaruhi apa yang akan dibeli oleh konsumen dan bagaimana mereka menggunakan produk atau jasa yang mereka beli

2. The process stage, tahapan ini memfokuskan pada bagaimana konsumen membuat keputusan. Dalam diri setiap individu terjadi proses pengambilan keputusan yaitu bereaksinya area psikologis yang membuat konsumen sadar akan kebutuhan, kemudia konsumen mencari informasi ssebelum membeli dan terakhir mengevaluasi alternatif-alternatif yang ada. Konsumen juga dapat mengevaluasi pembelian dengan mempertimbangkan pengalaman membeli sebelumnya.

3. The output stage, setelah sebuah keputusan untuk membeli produk atau jasa tertentu, konsumen melakukan trial dan melakukan pembelian ulang. Langkah yang terakhir setelah membeli adalah mengevaluasi pembelian, dimana evaluasi pembelian ini akan dijadikan salah satu dasar bagi pengambilan keputusan pembelian berikutnya.

\section{Perilaku Konsumen Online}

Istilah konsumen sering diartikan sebagai dua jenis konsumen, yaitu konsumen individu dan konsumen organisasi. Barang dan jasa yang dibeli oleh konsumen individu dapat digunakan untuk diri sendiri, anggota keluarga atau diberikan pada orang lain sebagai hadiah. Dalam konteks barang dan jasa yang dibeli kemudian digunakan langsung oleh individu maka individu tersebut dinamakan pemakai akhir atau konsumen akhir. Konsumen organisasi meliputi organisasi bisnis, yayasan, lembaga sosial, kantor pemerintah dan lembaga lainnya yang membeli produk, peralatan dan jasa untuk menjalankan organisasinya.

Terdapat beberapa definisi perilaku konsumen. Definisi perilaku konsumen menurut Engel, et al. (1993:4) adalah sebagai berikut: "Consumer behavior as those activities directly involved in obtaining, consuming, and disposing of products and services, including the decision processes that precede and follow these actions". Schiffman dan Kanuk (1994:7), mendefinisikan perilaku konsumen sebagai berikut: "The term consumer behavior refers to the behavior that consumers display in searching for, 
purchasing, using, evaluating, and disposing of products and services that they expect will satisfy their needs". Wilkie (1990:12), mendefinikikan perilaku konsumen sebagai berikut: "The activities that people engage in when selecting, purchasing, and using product and services so as to satisfy needs and desires. Such activities involve mental and emotional processes, in addition to physical actions".

Berdasarkan pendapat para ahli di atas dapat disimpulkan bahwa perilaku konsumen online adalah tindakan-tindakan yang dilakukan oleh individu, kelompok atau organisasi yang berhubungan dengan proses pengambilan keputusan dalam mendapatkan barang secara online, menggunakan barangbarang atau jasa ekonomis yang dapat dipengaruhi oleh lingkungan.

\section{Perceived Risk}

Resiko yang dirasakan didefinisikan sebagai ketidakpastian yang dihadapi para konsumen jika mereka tidak dapat meramalkan konsekuensi keputusan mereka (Shiffman \& Kanuk, 2008). Dalam penelitian konsumen, risiko berarti situasi dimana konsumen tidak mengetahui konsekuensi dari alternatif atau kemungkinan terjadinya kerugian dari hasil pembelian yang dilakukan ( $\mathrm{Ha}$, 2002).

Resiko didefinisikan sebagai situasi dimana pembuat keputusan memiliki pengetahuan apriori konsekuensi yang merugikan dan kemungkinana terjadinya. Selain itu, ketidakpastian didefinisikan sebagai suatu situasi dimana pembuat keputusan tahu bahwa hasil yang mungkin untuk setiap alternatif dapat diidentifikasi, namu tidak ada pengetahuan tentang probabilitas yang melekat masing-masing (Shiffman \& Kanuk, 2008)

Perceived risk berarti keyakinan subyektif individu tentang potensi konsekuensi negatif dari keputusan yang diambil konusmen (M. Samadi dan A yaghoob-Nejadi, 2009). Harus ditekankan bahwa para konsumen dipengaruhi oleh berbagai resiko yang mereka rasakan, apakah resiko itu betul-betul ada atau tidak. Risiko yang dirasakan adalah konsep fundamental dan perilaku konsumen yang menyiratkan pengalaman konsumen pra-pembelian ketidakpastian mengenai jenis dan tingkat kerugian yang diperkirakan akibat dari pembelian dan penggunaan produk. Dalam penelitian ini, perceived risk didefinisikan sebagai potensi terjadinya kerugian atau konsekuensi negatif terhadap upaya untuk mendapatkan hasil yang diinginkan oleh konsumen dalam berbelanja secara online melalui media jejaring sosial facebook.

\section{Jenis-jenis Perceived Risk Konsumen}

Dalam penelitian yang dilakukan oleh Hanjun KO, Jaemin Jung, Joo Young Kim, dan Sung Wook Shim (2004) yang berjudul "Cross-cultural Differences in Perceived Risk of Online Shopping”, Dimensi perceived risk yang digunakan adalah:

1. Social risk; adalah persepsi bahwa sebuah produk yang dibeli mungkin akan mendapat respon negatif (penolakan atau celaan) dari keluarga atau teman.

2. Financial risk; adalah persepsi bahwa sejumlah uang tertentu bisa hilang atau diperlukan untuk membuat sebuah produk bekerja dengan baik

3. Physical risk; adalah persepsi bahwa sebuah produk mungkin berbahaya bagi kesehatan ataupun keselamatan ketika produk tersebut tidak bekerja dengan baik 
4. Performance risk; adalah persepsi bahwa sebuah produk yang dibeli mungkin tidak akan berfungsi sesuai dengan ketentuan seharusnya atau sesuai dengan keinginan.

5. Time risk; adalah persepsi bahwa waktu yang mungkin akan terbuang ketika suatu produk yang dibeli harus diperbaiki terlebih dahulu atau diganti

6. Privacy risk; adalah potensi kehilangan kontrol atas informasi pribadi.

Sedangkan dalam penelitian YE Naiyi (2004) yang berjudul "Dimension of Customer's Perceived risk in Online Shopping", dimensi Perceived risk yang digunakan adalah;

1. Fraud risk mengacu pada perhatian konsumen mengenai kepercayaan terhadap penjual pada online shopping.

2. Delivery risk mengacu pada perhatian konsumen mengenai proses pengiriman barang.

3. Financial risk mengacu pada perhatian konsumen mengenaik kemungkinan kehilangan uang ketika berbelanja melalui internet.

4. Procees dan time risk mengacu pada pandangan terhadap waktu, kemudahan dan kenyamanan konsumen mengenai berbelanja melalui internet.

5. Product risk mengacu pada kualitas sebuah produk, kinerjanya, kepalsuan produk dan masalah lain yang berhubungan dengan produk tersebut.

6. Privacy risk mengacu pada perhatian konsumen mengenai keamanan dari informasi pribadi ketika berbelanja secara online.

7. Information risk mengacu pada perhatian konsumen terhadap ketiaksesuaian informasi mengenai penjua ataupun produk.

Dalam penelitian ini, penulis membatasi kategori responden pembeli online menjadi lebih spesifik yaitu konsumen yang berbelanja produk pakaian dan acessories secara online melalui media jejaring sosial facebook. Berdasarkan elaborasi dan penyesuaian yang dilakukan maka penulis memasukkan delapan dimensi perceived risk dalam penelitian ini antara lain: Financial Risk, Psycological risk, Time risk, Privacy risk, Fraud risk, Product risk, Information risk, dan Delivery risk.

\section{METODOLOGI PENELITIAN}

\section{A. Populasi, Sampel, dan Pengumpulan Data}

Populasi dalam penelitian ini adalah seluruh mahasiswa Politeknik Negeri Samarinda. Pemilihan sampel dilakukan dengan menggunakan metode purposive sampling dengan kriteria memiliki akun facebook dan pernah melakukan pembelian online di facebook. Data dalam penelitian ini dikumpulkan dengan menggunakan metode survey dengan menyebarkan kuisioner. Pengujian terhadap hipotesis yang diajukan dalam penelitian ini menggunakan regresi berganda dengan sampel minimal 30 orang dan menggunakan alat bantu SPSS sebagai dasar dalam menganalisis untuk membuktikan hipotesis yang diajukan.

\section{B. Instrumen Penelitian}

Variabel dalam penelitian ini terdiri dari perceived risk dan keputusan pembelian. Variabel perceived risk dilihat dari dimensi financial, psychological, time, privacy, fraud, product, information, dan delivery risk. Sedangkan variabel keputusan pembelian dilihat dari tiga tahapan yaitu the input stage, the process 
stage, the output stage. Variabel perceived risk dan keputusan pembelian diukur dengan menggunakan skala likert 1 sampai 6 .

\section{Uji Validitas}

Uji validitas dimaksudkan untuk mengukur sejauh mana instrument yang digunakan benar-benar mengukur yang seharusnya diukur (Cooper dan Schindler, 2003). Suatu alat ukur dikatakan mempunyai validitas tinggi jika alat ukur tersebut menjalankan fungsi ukurnya.

Penelitian ini menggunakan korelasi bivariate untuk menguji validitas konstruk (construct validity). Validitas konstruk menunjukkan seberapa baik hasil yang diperoleh dari penggunaan suatu pengukuran sesuai teori-teori yang digunakan untuk mendefenisikan suatu konstruk (Jogiyanto, 2004).

\section{Uji Reabilitas}

Reabilitas (reability) suatu pengukur menunjukkan akurasi, konsistensi dan ketepatan dari pengukurnya pengukur stabilitas dan konsistensi suatu instrument (Jogiyanto, 2004). Suatu pengukur stabilitas realibel (andal) sepanjang pengukur tersebut menghasilkan hasil-hasil yang konsisten (Cooper dan Schindler, 2003).

Pengujian terhadap reabilitas instrument menggunakan croncbach's alpha yang mencerminkan konsistensi suatu alat ukur. Koefisien reabilitas ditunjukkan oleh koefisien alpha $(\infty)$ croncbach yang berkisar antara nol sampai satu, semakin tinggi nilai koefisien semakin tinggi tingkat keandalan alat ukur yang digunakan. Reabilitas yang sedang antara 0,5 sampai 0,6 sudah cukup untk menjustifikasi sebuah penelitian (Nunally dan Bernstein, 1994).

\section{E. UJI ASUMSI KLASIK}

\section{Uji Multikolinieritas}

Uji multikolinieritas bertujuan untuk menguji apakah model regresi ditemukan adanya korelasi antar variabel bebas (independen). Model regresi yang baik seharusnya tidak terjadi korelasi diantara variabel independen. Jika variabel independen saling berkorelasi, maka veriabel tersebut tidak orthogonal. Variabel orthogonal adalah variabel independen yang nilai korelasi antar sesame variabel independen sama dengan nol.

Untuk mendeteksi ada atau tidaknya multikolineritas didalam model regresi menurut Ghozali (2005) adalah sebagai berikut :

a. Jika antar variable independen ada korelasi cukup tinggi (umumnya diatas $0,90)$. Maka hal ini mengindikasikan adanya multikolonieritas.

b. Multikolonieritas dapat dilihat dari nilai tolerance dan variance inflation factor (VIF). Nilai Cutoff yang umum dipakai untuk menunjukkan adanya multikoloneritas adalah nilai tolerance kurang dari 0,10 atau sama dengan nilai VIF lebih dari 10.

\section{Uji Autokorelasi}

Uji autokorelasi bertujuan menguji apakah dalam model regresi liniear ada korelasi antara kesalahan pengganggu pada periode $t$ dengan kesalahan penganggu pada periode t-1 (sebelumnya). Jika terjadi korelasi, maka dinamakan problem autokorelasi. 
Uji autokorelasi ini menggunakan DW test (Uji Durbin Watson). DW test hanya digunakan untuk uji autokorelasi tingkat satu dan masyarakat adanya konstanta dalam model regresi dan tidak variabel lag di antara variabel independen.

\section{Uji Normalitas}

Uji normalitas bertujuan untuk menguji apakah model regresi, variabel dan penggganggu atau residual memiliki distribusi normal. Uji $t$ dan $F$ mengasumsikan bahwa bahwa nilai residual mengikuti distribusi normal. Jika asumsi ini dilanggar maka uji statistic menjadi tidak valid untuk jumlah sampel kecil. Cara untuk mendeteksi apakah residual berdistribusi normal atau tidak yaitu dengan analisa grafik dan uji statistic.

\section{F. Pengujian Hipotesis}

Pengujian hipotesis penelitian ini menggunakan sofware SPSS 16.00. Data akan diolah untuk mendapatkan informasi deskriptif dan pengujian hipotesis perangkat lunak untuk analisis deskriptif menggunakan SPSS 16.00 for windows

Uji independen sample z test (uji z) digunakan dalam penelitian ini karena sampel yang digunakan lebih dari 30, akan tetapi SPSS tidak menyediakan fasilitas uji z dalam bentuk analisisnya. Walaupun demikian, uji z tetap dengan mudah dilakukan dengan menggunakan uji t, jadi hasil yang didapatkan ditafsirkan sebagai perolehan z; seperti t hitung pada sampel sama besar dengan angka $z$ hitung (Singgih Santoso, 2009)

\section{PEMBAHASAN}

\section{A. $\quad$ Analisis Independent Sample Z Test}

Penelitian ini merupakan penelitian multivariate dimana variabel penelitian yang akan diuji dalam penelitian ini yaitu pengaruh perceived risk terhadap keputusan membeli produk online. Variabel perceived risk diukur dengan menggunakan delapan dimensi sedangkan keputusan membeli diukur dengan menggunakan tahapannya. Seperti yang telah dijelaskan pada bab sebelumnya, uji $Z$ dilakukan dengan menggunakan uji t, jadi hasil yang didapatkan ditafsirkan sebagai perolehan $Z$; seperti t hitung pada sampel besar sama dengan angka $Z$ hitung (Singgih Santoso, 2009). Sehingga data yang ada tetap diolah dengan menggunakan uji t.

Setelah data awal diperoleh dari pengumpulan kuisioner kepada 200 responden yang kemudian yang mengembalikan hanya 150 responden dan data diolah untuk mendapatkan hasil dari analisis independen sample t test

Berdasarkan hasil analisis dapat disimpulkan bahwa perceived risk berpengaruh terhadap keputusan membeli prodek online. Hal ini mengindikasikan bahwa resiko merupakan salah satu alasan yang diperhitungkan dalam melakukan keputusan membeli produk online. Resiko merupakan hal penting yang harus dipertimbangkan dalam melakukan pembelian produk online karena transaksi yang dilakukan antara penjual dan pembeli tidak secara langsung (tatap muka) melainkan melalui media sosial sehingga 
dikhawatirkan menimbulkan resiko yang dapat merugikan, khususnya untuk pihak pembeli.

\section{Dimensi financial}

Pada dimensi ini dapat dilihat hasil yang diperoleh tidak berpengaruh. Hal ini menunjukkan bahwa resiko yang ditimbulkan dari segi keuangan tidak mempengaruhi keputusan pembelian secara online. Produk yang dijual secara online kebanyakan harganya lebih murah jika dibandingkan dengan melakukan pembelian secara langsung, hal ini dikarenakan produk yang dijual secara online memiliki kualitas yang kurang baik sehingga sesuai dengan harga yang ditawarkan.

Selain itu dewasa ini, transaksi jual beli melalui online kebanyakan dilakukan dengan syarat atau perjanjian barang diterima terlebih dahulu oleh pembeli kemudian barulah pembayaran dilakukan. Hal ini dilakukan untuk menghidari resiko khususnya resiko yang akan diderita para pembeli yang melakukan pembelian secara online.

\section{Dimensi psychological}

Pada dimensi ini juga tidak mempengaruhi keputusan pembeli untuk melakukan transaksi, hal ini mengindikasikan bahwa pada dasarnya produk yang ditawarkan pada media online kebanyakan kualitasnya kurang baik karena pembeli hanya melihat produknya melalui media tanpa melihat langsung produk yang akan dibeli. Harga produk yang ditawarkan secara online lebih murah jika dibandingkan dengan harga pasar yang ada, sehingga dapat disimpulkan bahwa harga mencerminkan kualitas dimana ketika produk yang ditawarkan lebih murah maka kualitasnya kurang jika dibandingkan dengan produk yang ditawarkan lebih mahal.

\section{Dimensi waktu}

Pada dimensi ini berdasarkan hasil yang diperoleh tidak berpengaruh terhadap keputusan untuk melakukan pembelian secara online. Ketika melakukan pembelian produk secara online akan terasa sangat berbeda jika dibandingkan dengan melakukan transaksi secara langsung. Jika melakukan transaksi secara langsung maka pembeli akan menerima langsung produknya di saat itu juga namun jika melakukan pembelian secara online maka pembeli tidak akan mendapatkan produknya secara online, hal ini dikarenakan adanya proses pengiriman barang yang membutuhkan waktu, selain itu juga orang yang menjual tidak memiliki barangnya atau merupakan tangan kedua dimana produknya harus dipesan terlebih dahulu kepada penjual asli (pertama) kemudian barulah dikirimkan kepada pembelinya.

\section{Dimensi privacy}

Berdasarkan hasil yang diperoleh yang diperoleh dapat disimpulkan bahwa dimensi privacy tidak berpengaruh terhadap keputusan pembeli untuk melakukan transaski pembelian. Hal ini dapat dilihat bahwa ketika melakukan pembelian secara online maka pembeli harus benar-benar memberikan data diri yang sesungguhnya karena jika tidak maka kegagalan dalam transaksi dapat terjadi, sebagai contoh, alamat rumah atau nomor telepon yang dapat dihubungi 
tidak fiktif karena terkait dengan proses pengiriman barang serta konfirmasi mengenai barang yang telah dikirim sudah diterima atau belum oleh pembeli.

Selain itu data pribadi pembeli produk tidak terjamin aman dan dapat diakses dengan mudah oleh pihak-pihak yang tidak bertanggung jawab (hacker) sehingga dapat menimbulkan kerugian bagi pihak pembeli. Serangan hacker ini sulit untuk dilacak dan perundang-undangan yang diterapkan di Indonesia juga belum memberikan efek jera terhadap pelakunya.

\section{Dimensi fraud}

Berdasarkan hasil yang ada maka dapat ditarik kesimpulan bahwa dimensi fraud ini berpengaruh terhadap keputusan pembelian secara online. Hal ini mengindikasikan bahwa maraknya penipuan yang terjadi membuat pembeli untuk membuat keputusan untuk membeli produk tersebut atau tidak. Penipuan yang terjadi sangat merugikan pembeli, khususnya ketika produk yang diharapkan pembeli tidak sesuai.

Kemudian penjual produk online juga sering melakukan penipuan, misalnya dalam hal produk yang dijual, dimana kebanyakan para penjual mencantumkan akan menerima kembali barang apabila terdapat kerusakan namun dalam kenyataan setelah produk terjual dan ketika dikembalikan kepada penjual, si pembeli akan mengeluarkan biaya tambahan berupa pengiriman kembali barang yang rusak tersebut. Selain itu juga, penjual tidak mau bertanggung jawab atas kerusakan barang yang telah dikirim, hal ini sematamata dikarenakan kerugian yang akan diderita oleh penjual.

\section{Dimensi product risk}

Pada dimensi ini juga tidak mempengaruhi keputusan pembeli untuk melakukan pembelian produk secara online. Hal ini didasarkan pada banyak hal antara lain mengenai produk yang ditawarkan penjual tidak sesuai dengan yang diharapkan pembeli, kualitas produk yang ada juga kurang baik. Kebanyakan produk yang ditawarkan melalui media online juga bukan merupakan produk asli sehingga sering mengecewakan pembelinya.

Dengan adanya beberapa alasan yang telah diungkapkan maka pembeli akan berpikir ulang untuk melakukan transaksi melalui media online. Hal ini juga lah yang membuat pembeli tidak ingin menanggung resiko dalam bertransaksi.

\section{Dimensi informasi}

Hasil yang diperoleh menunjukkan bahwa dimensi informasi berpengaruh terhadap keputusan pembeli untuk melakukan pembelian produk secara online. Informasi mengenai produk yang ditawarkan sangatlah penting bagi pembeli, karena informasi ini menyangkut semua yang berhubungan dengan produk yang ditawarkan.

Informasi yang disampaikan oleh penjual harus jelas dan tidak menimbulkan keragu-raguan. Sehingga ketika pembeli mendapatkan informasi yang baik dari penjual maka akan membuat pembeli untuk melakukan keputusan pembelian. Selain itu informasi mengenai manfaat dan kegunaan produk sangatlah mempengaruhi keputusan pembeli. 


\section{Dimensi delivery}

Berdasarkan hasil yang diperoleh dapat disimpulkan bahwa dimensi ini berpengaruh terhadap keputusan pembelian produk online. Proses pengiriman barang yang dilakukan oleh pihak penjual sangat mempengaruhi keputusan pembelian produk online, hal ini didasarkan pada waktu yang digunakan untuk mengirim barang tersebut, kemudian mengenai jasa pengiriman yang digunakan penjual dalam mengirimkan barangnya. Dimana semua ini menjadi bahan pertimbangan dalam mengambil keputusan untuk melakukan pembelian produk online.

Mengenai proses pengiriman barang pihak pembeli dapat langsung mengkonfirmasi nomor resi pengiriman barang yang telah diberikan oleh penjual melalui jasa pengiriman barang yang digunakan. Hal ini dilakukan oleh pihak pembeli agar dapat mengetahui produk yang dibeli tersebut sudah dikirim atau belum. Jasa pengiriman barang digunakan oleh penjual juga harus terpercaya sehingga ketika produk yang dikirim nantinya akan diterima pembeli dalam keadaan baik tanpa cacat serta tidak membutuhkan waktu yang tidak begitu lama untuk mendapatkan produk tersebut.

\section{KESIMPULAN}

\section{A. Kesimpulan}

Berdasarkan hasil yang diperoleh dapat disimpilkan bahwa secara garis besar perceived risk berpengaruh terhadap keputusan pembelian produk online. Namun ketika menggunakan uji t maka dalam variabel perceived risk yang diukur dengan menggunakan 8 dimensi maka tidak semua dimensi ini mempengaruhi keputusan pembelian produk online.

Pada dimensi financial, psychological, waktu, privacy, dan product risk tidak berpengaruh terhadap keputusan pembelian produk online. Sedangkan untuk dimensi fraud, informasi, dan delivery berpengaruh terhadap keputusan untuk melakukan pembelian produk online

\section{B. Saran}

Berdasarkan kesimpulan yang telah diperoleh dalam penelitian ini maka saran yang dapat diberikan pada penelitian selanjutnya adalah :

1. Penelitian selanjutnya dapat menambah variabel lain selain variabel perceived risk.

2. Penelitian selanjutnya agar dapat menggunakan alat analisis yang lain guna memperkuat maupun menentang hasil penelitian ini.

\section{DAFTAR PUSTAKA}

Cooper, D.R. dan Scindler, P.S. (2003), Business Research Method. Mc Graw Hill, $8^{\text {Th }}$ ED

Cowles, Deborah,.L, Pamela \& Little, Michael W. (2002), Using key informant Insight as a foundation for e- retailing theory development. Journal of Business Reseaarch 55, pp. 629-636. 
Demirdogen, Osman. Sukru Yaprakli. Mustafa Kemal Yilmaz. Jamaluddin Husain. 2010. Customer Risk Perceptions of Internet Banking - A Study in Turkey. Journal of Applied Business Research. Vol 26 No 6

Engel, JF., Blackwell, RD., \& Miniard, PW., 1993. Consumer Behavior. Seventh Edition. USA: The Dryden Press

Ghozali, Imam. (2005), Aplikasi analisis Multivariate dengan Program

SPSS. Edisi ketiga, BP Undip.

$\mathrm{Ha}, \mathrm{H}-\mathrm{Y}$. (2002). The Relationships between 3-D Advertisings and Risk Perception on the Web : the Mediating Role of Brand and Emotion. Unpublished Working Paper. UMIST. UK

Jarvenpaa S.L. dan Tractinsky, N. (1999), Cunsumer trust in an Internet store:Across-cultural Validation. Journal of Computer-Mediated Communicatinon, Dec, 1-35

Jogiyanto H.M. (2004), Metode Penelitian Bisnis : Salah Kaprah dan Pengalaman-Pengalaman, BPFE-Yogyakarta.

Ko, Hanjun, Jaemin Jung, Joo Young Kim, dan Sung Wook Shim. 2004. Crosscultural Differences in Perceived Risk of Online Shopiing. Journal of Interactive Advertising. Vol 4 No 2 (Spring), pp.20-29

Kotler, Philip. 2006. Manajemen Pemasaran Edisi 11. Jakarta: $\quad$ PT. Indeks

Loudon, David L. dan Albert J. Della Bitta. 2001. Consumer Behavior: Concepts and Applications. McGraw-Hill Inc., USA

Naiyi, Y.E. (2004). Dimensions of Consumer's Perceived Risk in Online Shopping Journal of Electronic Science and Technology of China Vol.2 No.3

Nunnally, J.C., dan Ira H. Bernstein.(1994), Psycometric Theory. Third Edition, MC Graw Hill, Inc., New York.

Samadi, Mansour dan Ali Yaghoob-Nejadi. 2009. A Survey of the Effect of Consumers Perceived Risk on Purchase Intention in E-Shopping. Business Intelligence Journal. 261-275

Schiffman, Leon \& Kanuk, Leslie Lazer, 2008. Perilaku Konsumen, edisi ketujuh. Jakarta : Indeks.

Stone, RN. and K. Gronhaug. 1993. Perceived Risk: Further Considerations for the Marketing Discipline. European Journal of Marketing. 27 (3). 39-50.

Urbaczewski, A., Jessup L.M., dan Wheeler, B. 2002. Electronic Commerce Research ; A Taxonomy an Shynthesis. Journal of Organizational Computing and Electronic Commerce 12 (4), 263-305

Wilkie, Wieliam, L. 1990. Consumer Behavior. $2^{\text {nd }}$ Edition. Canada. John Wiley\& Sons, Inc 